\title{
PERINGATAN DINI PUTING BELIUNG DI DAERAH ISTIMEWA YOGYAKARTA
}

\author{
Emilya Nurjani $^{1}$, Ahmad Cahyadi ${ }^{2}$ dan Utia Suarma ${ }^{3}$ \\ ${ }^{1}$ Departemen Geografi Lingkungan, Fakultas Geografi, Universitas Gadjah Mada, n_emilya@yahoo.com \\ ${ }^{2}$ Departemen Geografi Lingkungan, Fakultas Geografi, Universitas Gadjah Mada, ahmadcahyadi@geo.ugm.ac.id \\ ${ }^{3}$ Departemen Geografi Lingkungan, Fakultas Geografi, Universitas Gadjah Mada, tiasuarma@gmail.com
}

\begin{abstract}
ABSTRAK
Penelitian ini bertujuan untuk mengetahui mekanisme peringatan dini puting beliung di Daerah Istimewa Yogyakarta (DIY). Metode pengumpulan data yang digunakan dalam penelitian ini adalah dengan melakukan diskusi kelompok terfokus dengan mengundang instansi pemerintah yang terkait dengan kajian. Mitigasi bencana puting beliung di DIY dilakukan berdasarkan informasi keterdapatan awan cumulonimbus yang disebar luaskan oleh Stasiun Klimatologi Yogyakarta, Badan Meteorologi, Klimatologi dan Geofisika (BMKG). Informasi diteruskan ke Badan Penanggulangan Bencana Daerah DIY dan kabupaten/kota, kemudian disebarkan ke relawan yang tergabung dalam Taruna Tanggap Bencana (TAGANA). Kendala yang dihadapi dalam pemberian informasi ini adalah bahwa kejadian puting beliung yang terjadi hanya merupakan prediksi dari kemungkinan kemunculan yang ditandai dengan keberadaan awan Cumulonimbus. Keterbatasan perekaman oleh radar cuaca yang melakukan perekaman setiap 30 menit sekali tidak dapat mengakomodasi kejadian puting beliung yang umumnya hanya terjadi selama 5 sampai 10 menit. Selain itu, singkatnya kejadian puting beliung yang singkat menyebabkan sulitnya penyebaran informasi dilakukan sebelum kejadian bencana terjadi.
\end{abstract}

Kata Kunci: Puting Beliung, Peringatan Dini, Daerah Istimewa Yogyakarta

\section{Pendahuluan}

Sebagai benua maritim, Indonesia memiliki dinamika atmosfer yang sangat dinamis [1]. Secara umum dinamika atmosfer di Indonesia sangat dinamis karena dipengaruhi oleh beberapa fenomena yang terdiri dari keberadaan Inter-Tropic Convergence Zone (ITCZ) El-Nino Southern Oscillation (ENSO), Madden-Jullian Oscillation (MJO), dan Dipole Mode [2,3,4,5,6,7]. Kondisi dinamika atmosfer yang sangat dinamis tersebut kemudian menyebabkan pengaruh pada variasi komponen iklim seperti suhu, curah hujan dan angina [4].

Secara lokal, kondisi dinamika atmosfer dapat dipengaruhi oleh topografi, penggunaan lahan dan kondisi lebih lokal dapat pula menyebabkan terjadinya bencana bagi manusia, misalnya angin ribut yang sifatnya merusak [9]. Jumlah kejadian angina ribut di Indonesia cenderung mengalami peningkatan di mana pada tahun 2008 terdapat jumlah angin ribut sejumlah 4.269 kali kejadian [8]. Kondisi serupa juga terjadi di Pulau Jawa di mana jumlah kejadian angina ribut terus mengalami kenaikan sejak tahun 1990 sampai dengan tahun 2011 (Gambar 1). Kejadian angin ribut di Indonesia paling banyak terdapat di Pulau Jawa (Gambar 2) dengan Propinsi Jawa Tengah sebagai propinsi dengan jumlah kejadian angina ribut paling banyak, yakni 400 kejadian angin ribut [9]. lingkungan lainnya [8]. Dinamika atmosfer pada skala yang 


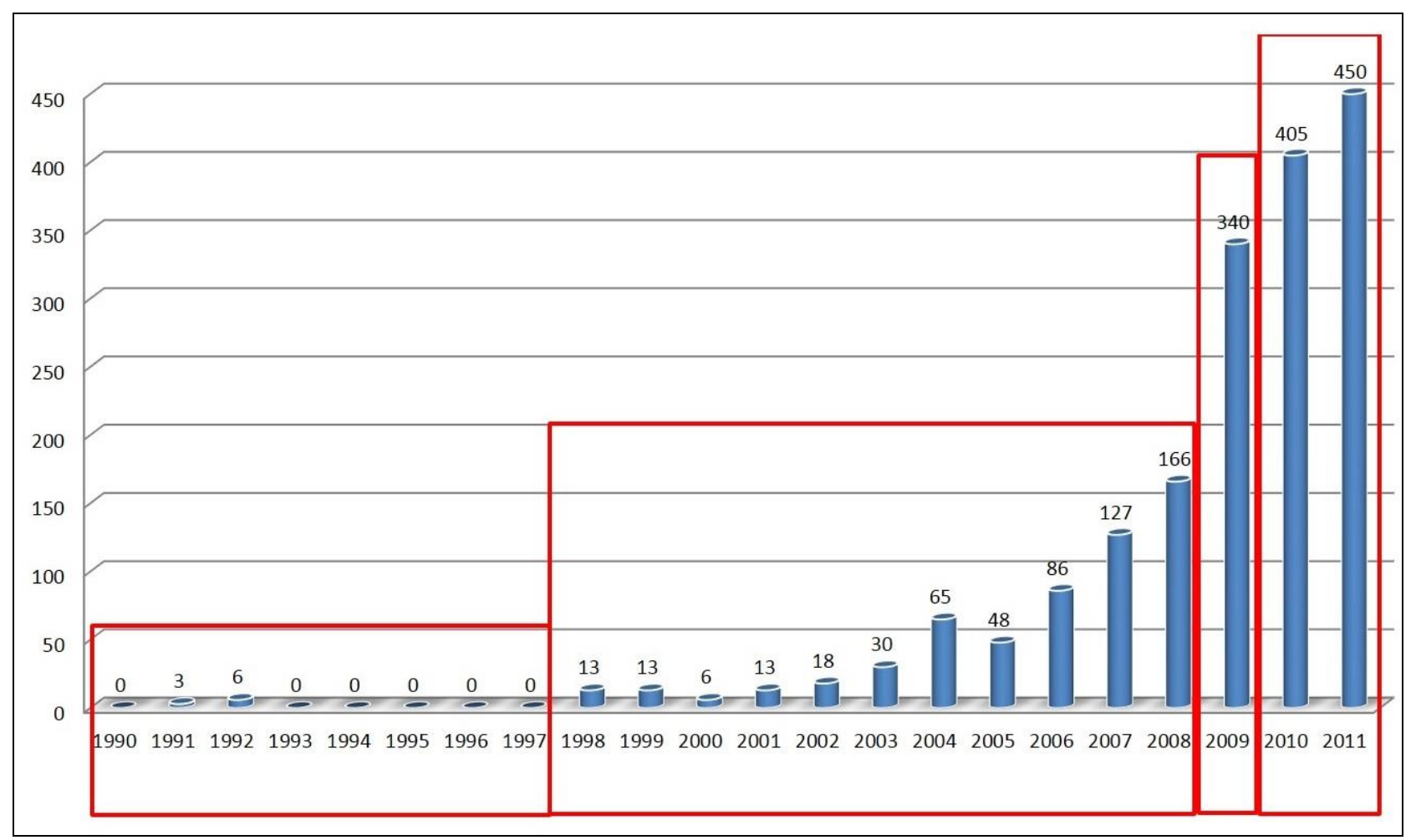

Gambar 2. Trend Kejadian Angin Ribut di Indonesia Periode Tahun 1990 - 2011 [8]

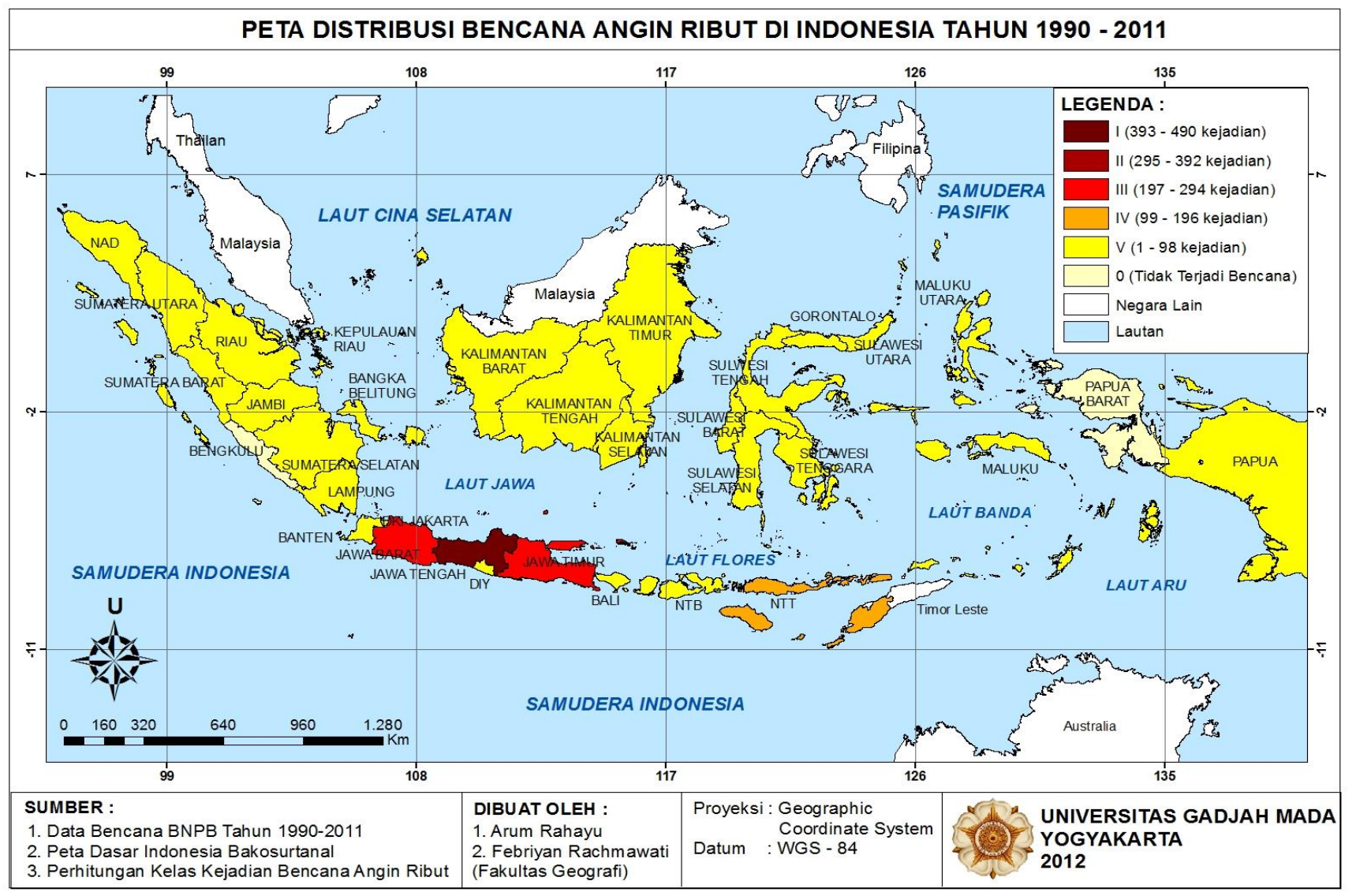

Gambar 2. Peta Jumlah Kejadian Angin Ribut di Indonesia Periode Tahun 1990 - 2011 [8]

Prosiding Seminar Nasional Geografi Lingkungan I, 27 November 2016 di Fakultas Geografi UGM Yogyakarta. Halaman 73 -79. ISBN 978-979-8786-65-5 
Kejadian angin ribut hampir merata terjadi di Daerah Istimewa Yogyakarta (DIY) dengan intensitas dan skala angin angin ribut yang berbeda-beda. Jumlah kejadian angin puting beliung di DIY adalah 194 kejadian selama kurun waktu 10 tahun, mulai tahun 2000 sampai dengan 2010 (Gambar 1 dan Gambar 2). Hal tersebut merupakan salah satu alasan mengapa daerah tersebut menjadi daerah kajian penelitian penulis.

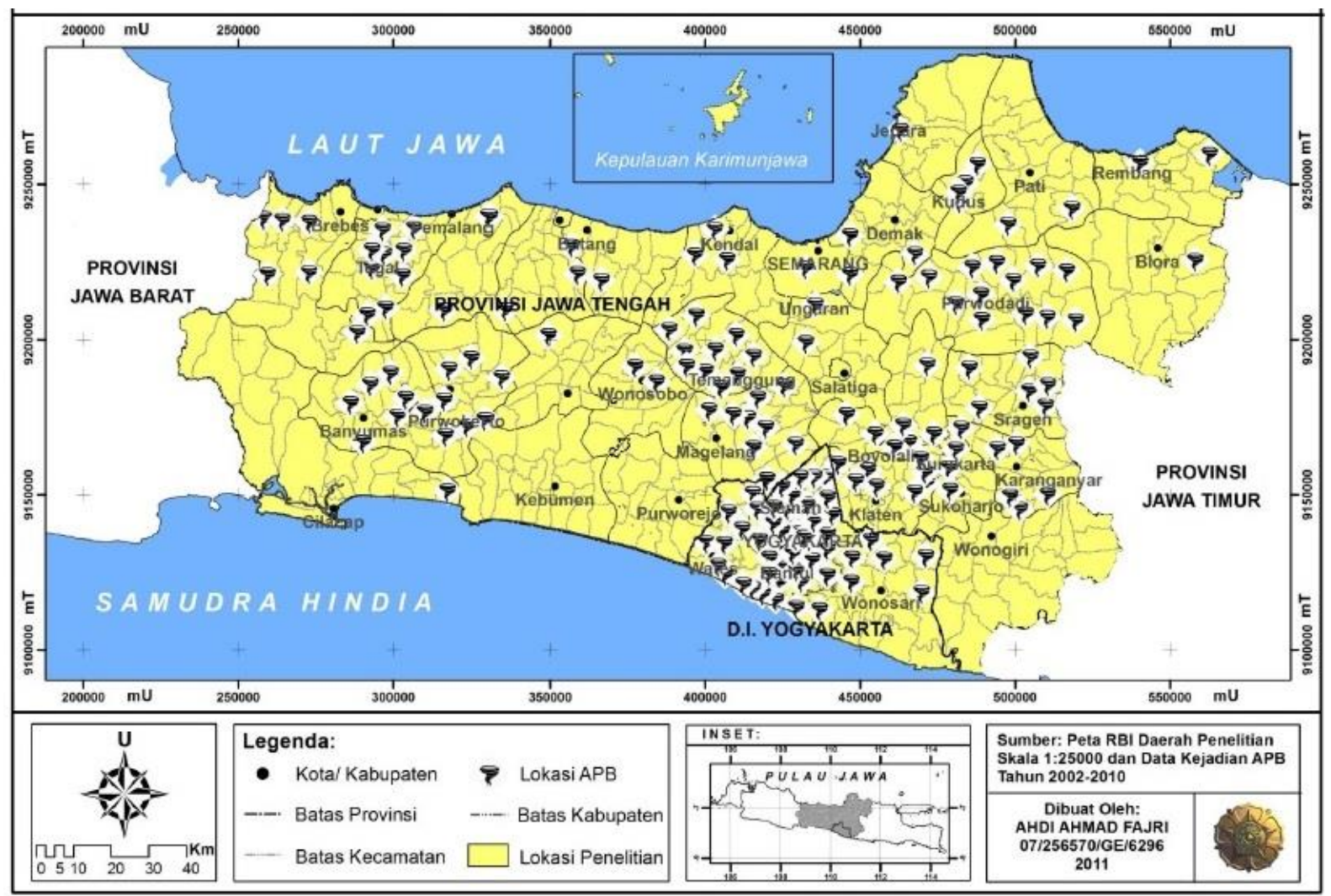

Gambar 3. Peta Kejadian Angin Ribut di DIY dan Jawa Tengah [9] 


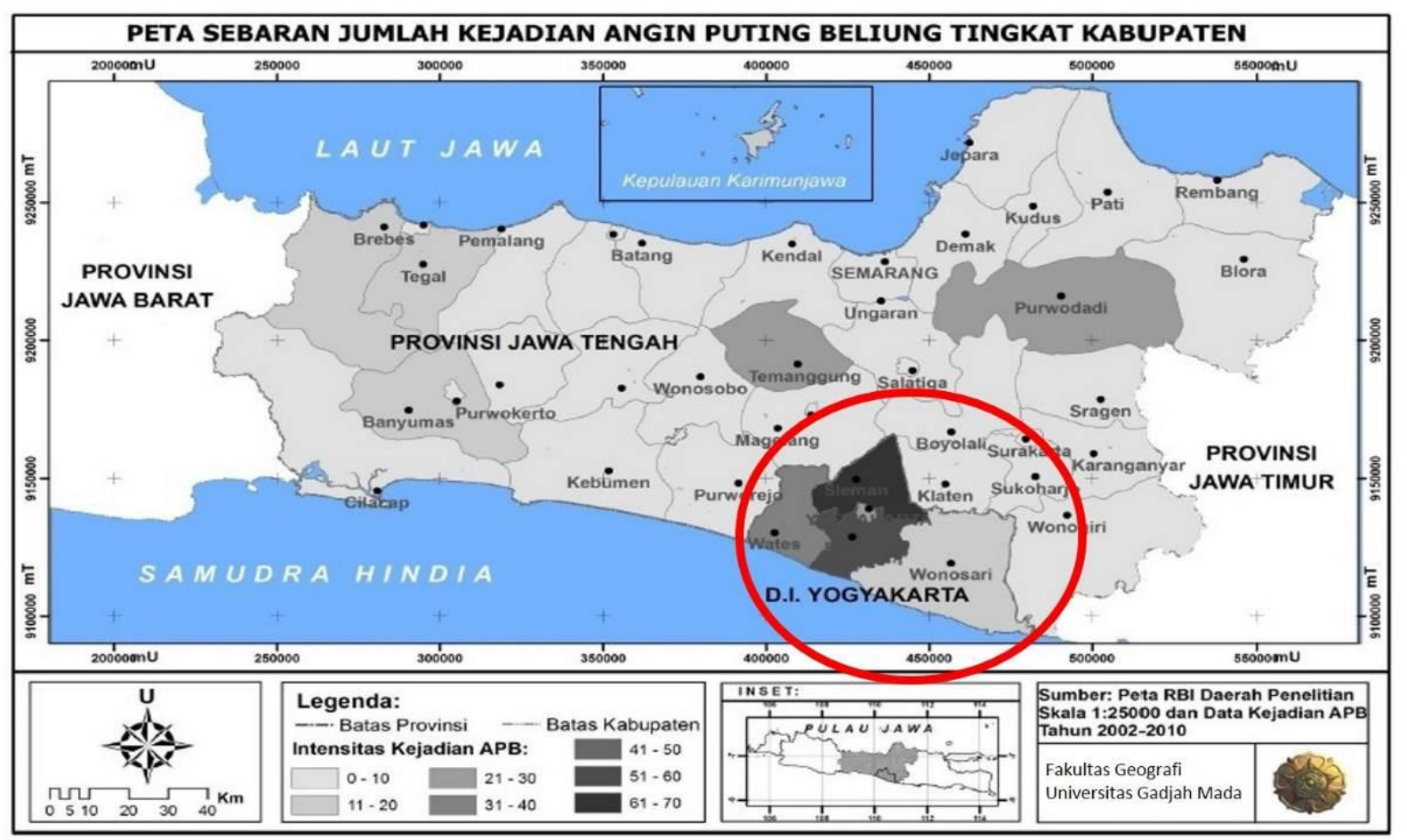

Gambar 4. Peta Jumlah Kejadian Angin Ribut di DIY dan Jawa Tengah [9]

Salah satu jenis angin ribut yang sangat merusak di Daerah Istimewa Yogyakarta adalah angin puting beliung. Angin puting beliung adalah angin ribut yang dicirikan dengan bentuk pusaran angina yang seperti corong. Angin ini bergerak dengan kecepatan yang tinggi, sehingga memungkinkan terjadinya kerusakan pada wilayah yang dilalui.

Kondisi penutup lahan yang sebagian besar merupakan permukiman juga merupakan salah satu alasan mengapa daerah tersebut menjadi daerah kajian. Letak Daerah Istimewa Yogyakarta dengan kondisi geografis mendukung terjadinya angin puting beliung karena dilihat dari letak lintang dan bujurnya, daerah ini merupakan daerah tropis yang memiliki kelembaban di atas $75 \%$ yang dapat menimbulkan terjadinya ketidakstabilan massa udara. Selain itu, suhu udara di daerah tropis tergolong tinggi, karena posisi Matahari berada di atas Pulau Jawa atau posisi Matahari selalu vertikal [9]. Letak Pulau Jawa yang dekat dengan Samudra Hindia dan Samudra Pasifik serta dekat dengan Benua Asia dan Benua Australia juga mempengaruhi terjadinya angin puting beliung.

Adanya perbedaan suhu di daratan dan lautan dapat Prosiding Seminar Nasional Geografi Lingkungan I, 27 November 2016 di Fakultas Geografi UGM Yogyakarta. Halaman 73 -79. ISBN 978-979-8786-65-5

memicu terjadinya angin puting beliung, serta adanya angin monsun barat dan angin monsun timur juga memicu terjadinya angin puting beliung tersebut [9]. Angin puting beliung sifatnya lokal baik faktor yang mempengaruhi maupun dampaknya. Artinya bahwa daerah yang terkena dampak dari kejadian tersebut sangat kecil dan faktor lokal seperti topografi, vegetasi, dan penutup lahan juga dapat mempengaruhi peningkatan suhu yang pada akhirnya mempengaruhi terjadinya angin puting beliung. Penelitian ini secara khusus bertujuan untuk mengetahui mekanisme peringatan dini puting beliung yang ada di Daerah Istimewa Yogyakarta.

\section{Metode Penelitian}

Metode pengumpulan data yang digunakan dalam penelitian ini adalah dengan melakukan diskusi kelompok terfokus (Focus Group Discussion/ FGD) dengan mengundang instansi pemerintah yang terkait dengan kajian seperti Badan Meteorologi, Klimatologi dan Geofisika Daerah Istimewa Yogyakarta yang dalam hal ini diwakili oleh Stasiun Klimatologi Yogyakarta, Badan Penanggulangan Bencana Daerah (BPBD) tingkat propinsi, kotamadya 
dan kabupaten (Gambar 5). FGD dilakukan dengan bahasan khusus terkait dengan mekanisme yang diterapkan, tugas pokok dan fungsi (tupoksi) dari masing-masing lembaga, kesulitan yang dihadapi serta pengalaman operasional di lapangan yang selama ini dijalankan.

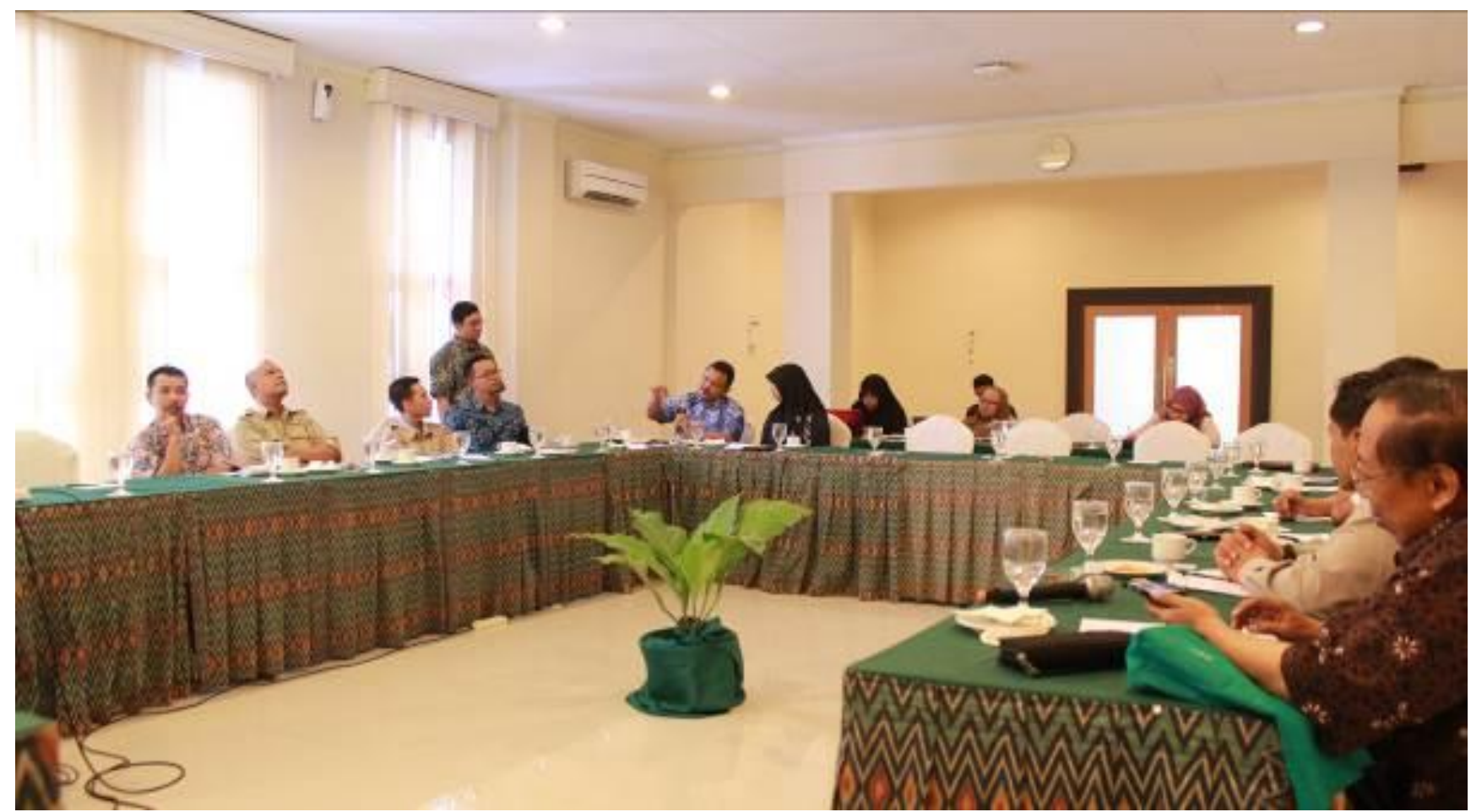

Gambar 5. Suasana FGD Terkait dengan Mekanisme Peringatan Dini Bencana Puting Beliung di DIY

\section{Hasil dan Pembahasan}

Mekanisme peringatan dini puting beliung hasil FGD ditunjukkan oleh Gambar 4. Informasi pertama dihasilkan oleh analisis citra radar cuaca di Stasiun Klimatologi Yogyakarta. Informasi ini kemudian diolah untuk menentukan curah hujan yang munkin terjadi (hujan ringan, sedang, lebat dan sangat lebat), keberadaan awan Cumulonimbus, kemungkinan terjadinya angin ribut termasuk puting beliung, serta wilayah-wilayah yang mungkin terdampak bencana hidrometeorologis. Informasi ini kemudian diteruskan ke BPBD tingkat propinsi, kotamadya dan ka- bupaten di Daerah Istimewa Yogyakarta. Selain itu, informasi ini akan disebarkan melalui media sosial seperti facebook dan tweeter serta forum mitigasi bencana hidrometeorologi yang tergabung dalam grup whatshap. Informasi melalui media sosial akan langsung dapat diterima masyarakat yang mengikuti sosial media dengan cepat, namun sulit dijamin bahwa informasi sudah sampai di masyarakat yang benar-benar akan terdampak. Oleh karenanya penyebaran informasi melalui instansi yang memiliki kedekatan dengan masyarakat seperti BPBD dan TAGANA akan sangat bermanfaat. 


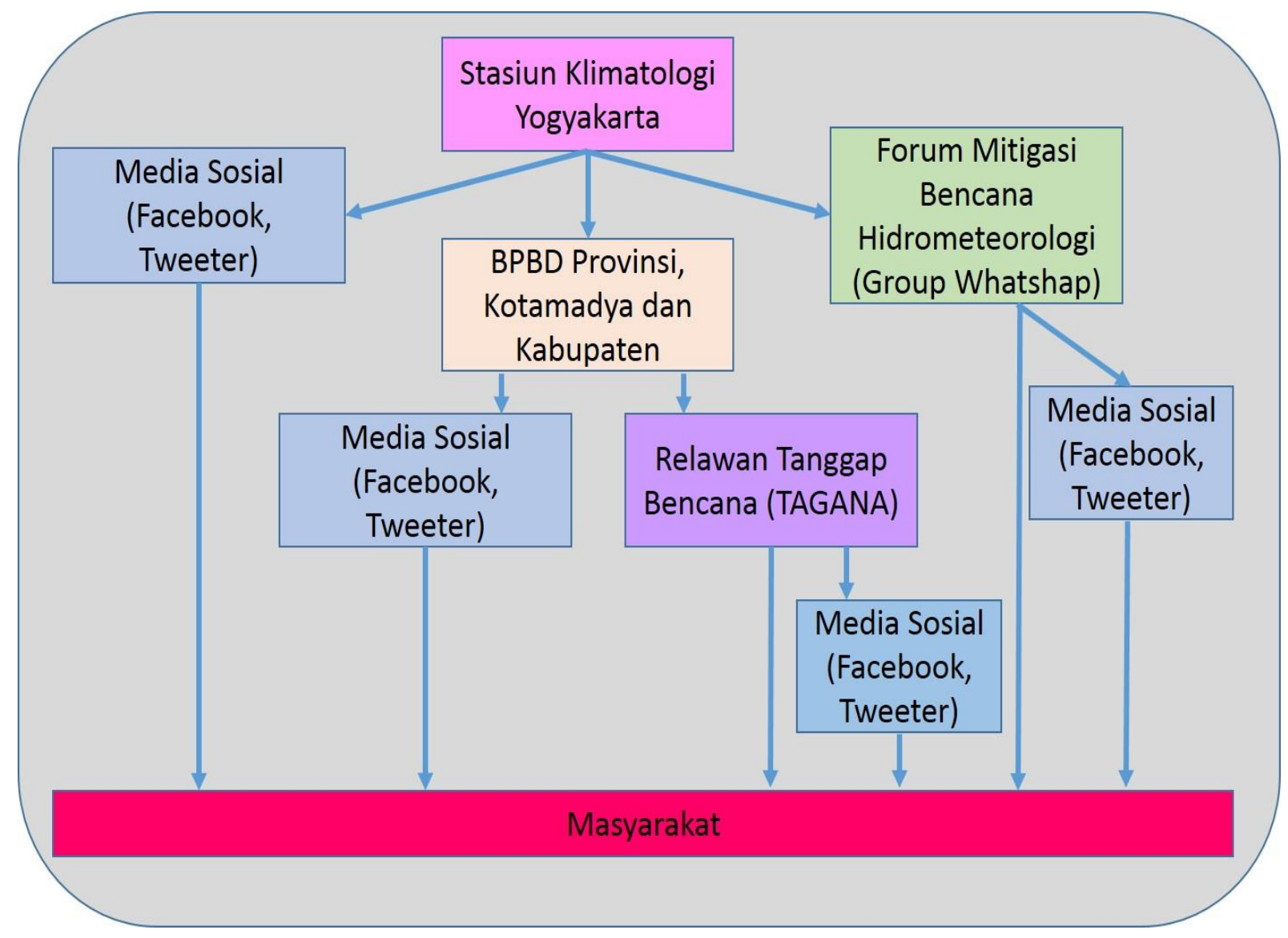

Gambar 4. Mekanisme Peringatan Dini Puting Beliung di Daerah Istimewa Yogakarta

Peringatan terkait dengan kondisi cuaca dan bencana hidrometeorologis akan diterima masyarakat dalam bentuk gambar berupa citra cuaca terkini dan teks/ deskripsi detail dari fenomena cuaca. Pengelaman yang penulis lakukan, informasi melalui media sosial akan diterima sangat cepat melalui media sosial, sedangkan informasi melalui whatshap ternyata baru akan diterima sekitar 5 menit sampai dengan 12 menit. Hal ini tentunya juga menjadi masalah karena kejadian puting beliung berlangsung dengan sangat cepat dengan durasi sekitar 5 sampai 10 menit. Namun demikian, dapat saja informasi yang disebarkan menjadi sangat bermanfaat mengingat informasi yang disebarkan didasarkan pada sebaran awan Comulonimbus yang sebenarnya dapat membentuk puting beliung dengan waktu yang relatif lama dari saat informasi tersebarkan.

Penyebaran informasi secara umum dilakukan sekitar 4 sampai 7 kali dalam sehari, namun sebenarnya radar cuaca merekam setiap 30 menit, sehingga jika terdapat kon- disi cuaca yang sangat berbahaya dapat pula segera disebarkan kepada masyarakat. Permasalahan yang pernah terjadi adalah bahwa dengan interval perekaman yang dilakukan setiap 30 menit menyebabkan fenomena puting beliung yang terjadi tidak dapat terdeteksi karena durasi kejadian maksimal hanya 10 menit. Kedua, interval 30 menitan belum dapat mengakomodasi peringatan dini puting beliung yang ideal, karena proses pembentukan dan durasi kejadian puting beliung yang sangat cepat. Ketiga, peralatan radar cuaca yang mahal dan canggih terkendala pada perawatan dan perbaikan yang harus dilakukan dengan mendatangkan ahli dari luar negeri. Hal ini menyebabkan perbaikan membutuhkan waktu yang lama dan biaya maintenance menjadi tinggi.

\section{Kesimpulan}

Mitigasi bencana puting beliung di DIY dilakukan berdasarkan informasi keterdapatan awan cumulonimbus ISBN 978-979-8786-65-5 
yang disebar luaskan oleh Stasiun Klimatologi Yogyakarta, Badan Meteorologi, Klimatologi dan Geofisika (BMKG). Informasi diteruskan ke Badan Penanggulangan Bencana Daerah DIY dan kabupaten/kota, kemudian disebarkan ke relawan yang tergabung dalam Taruna Tanggap Bencana (TAGANA). Kendala yang dihadapi dalam pemberian informasi ini adalah bahwa kejadian puting beliung yang terjadi hanya merupakan prediksi dari kemungkinan kemunculan yang ditandai dengan keberadaan awan $\mathrm{Cu}$ mulonimbus. Keterbatasan perekaman oleh radar cuaca yang melakukan perekaman setiap 30 menit sekali tidak dapat mengakomodasi kejadian puting beliung yang umumnya hanya terjadi selama 5 sampai 10 menit. Selain itu, singkatnya kejadian puting beliung yang singkat menyebabkan sulitnya penyebaran informasi dilakukan sebelum kejadian bencana terjadi.

\section{Pengakuan}

Penelitian ini merupakan bagian dari hibah Program Pengabdian Kepada Masyarakat Berbasis Pemanfaatan Hasil Penelitian dan Penerapan Teknologi Tepat Guna dengan Judul "Pembuatan Film Edukasi untuk Peningkatan Kapasitas Masyarakat di Daerah Istimewa Yogyakarta dalam Menghadapi Bencana Puting

Beliung” yang dibiayai oleh Bantuan Pendanaan Perguruan Tinggi Negeri Badan Hukum (BPPTN BH) Universitas Gadjah Mada. Peneliti mengucapkan terimakasih kepada semua pihak yang telah membantu terlaksananya kegiatan penelitian ini.

\section{REFERENSI}

[1] Marzuki, Hashiguchi, H., Yamamoto, Y.K., Yamamoto, M., Mori, S., Yamanaka, M.D., Carbone, R., Tuttle, J.D., 2013. Cloud episode propagation over the Indonesian maritime continent from 10 years of infrared brightness temperature observation. Atmospheric Research 120-121, pp. 268-286.

[2] Schott, F. \& McCreary, J., 2001. The monsoon circulation of the Indian Ocean. Progress in Oceanography Vol. 51, pp. 1-123.

[3] Nakazawa, T., 2000. MJO and tropical cyclone activity during 1997/98 ENSO. Advanced Space Research Vol. 25, pp. 953-958.

[4] Morita, J., Takayabu, Y., Shige, S. \& Kodama, Y., 2006. Analysis of rainfall characteristics of the madden-julian oscillation using TRMM satellite data. Dynamics of Atmosphere and Ocean Vol. 42, pp. 107-126.

[5] Nakazawa, T., 1995. Intraseasonal oscillation during the TOGA COARE IOP. Journal of Meteorological Society of Japan Vol. 73, pp. 305-319.

[6] Numaguti, A., Oki, R. \& Kodama, Y., 1993. 4-5 Day period variation and low level dry air observed in the equatorial western pacific during the TOGA-COARE IOP. Journal of Meteorological Society of Japan Vol 73, pp. 267-290.

[7] Salahuddin, A. and Curtis, S., 2011. Climate extremes in Malaysia and equatorial south china sea. Global and planetary change Vol. 78, pp. 83-91.

[8] Nurjani, E.; Rahayu, A. dan Rachmawati, F. 2013. Kajian Bencana Angin Ribut di Indonesia Periode 1990-2011. Laporan Penelitian. Fakultas Geografi Universitas Gadjah Mada.

[9] Fajri, A.A. 2011Pola Kejadian Angin Puting Beliung di Provinsi Jawa Tengah dan Daerah Istimewa Yogyakarta. Skripsi. Yogyakarta: Fakultas Geografi UGM. 